\title{
A Sociolinguistic Approach to Oral and Written Communication for Engineering Students
}

\author{
Chamnong Kaewpet (Corresponding author) \\ Faculty of Liberal Arts, Rajamangala University of Technology Krungthep \\ 2 Nanglinji Road, Tungmahamek, Sathorn, Bangkok 10120, Thailand \\ Tel: 66-85-901-3083Ｅ-mail: chamnong.k@rmutk.ac.th \\ Suphat Sukamolson \\ Chulalongkorn Language Institute, Chulalongkorn University \\ 254 Phayathai Road, Pathumwan, Bangkok 10330, Thailand \\ E-mail: suphat.s@chula.ac.th
}

$\begin{array}{lrr}\text { Received: April 26, } 2011 & \text { Accepted: May 21, } 2011 \quad \text { Published: October 1, } 2011 \\ \text { doi:10.5539/ass.v7n10p183 } & \text { URL: http://dx.doi.org/10.5539/ass.v7n10p183 }\end{array}$

This report is part of a two-year research project financed by Office of the Higher Education Commission, The Thailand Research Fund and Rajamangala University of Technology Krungthep (Contract No. MRG5380287).

\begin{abstract}
Engineering students are under pressure to achieve better English abilities required for international communication in the profession. This paper explores reports concerning English education for engineering and focuses on demands for oral and written communication, emphasizing oral presentations, professional conversations and report writing. A sociolinguistic picture of communicative events is examined for a general idea of English instruction. The examination indicates that incorporation of authentic communicative events into English courses has become a necessity to help students' transition from the classroom to the workplace. Moreover, the subject contents of communication should be adequately discipline-specific to enhance the value of training. The target level of comprehensibility of communication should be close to that of native speakers to succeed in real communication. Further research is recommended as demands vary from context to context.
\end{abstract}

Keywords: Communicative event, Engineering student, International communication, Oral and written communication, Sociolinguistics

\section{Demands for English in engineering}

English has been identified as the international communication tool in engineering all around the world. In Europe, English is used as the default language (Bjorkman, 2008) as countries participate in the Bologna process. This has led to increased academic mobility and student exchanges. In South Africa, English is a key ingredient as the engineering profession normally operates from a global business network (Hill \& Zyl, 2000). In China, professional English training programs are offered every year for engineers and technical staff (Chen, 2006). English continues to rise as one of the world's dominant languages (Graddol, 1997, 2000).

Engineering graduates are required to communicate and function effectively both in domestic and international environments (Accreditation Board for Engineering and Technology, 1998-2010; European Accreditation of Engineering Programmes, 2008). In today's professional practice, engineers must complement technical skills with critical skills through English such as "analyze other cultures' needs, and design products and services to fit those needs." Engineers must also be "aware of customs, laws, and ways of thinking in other countries... understand and accept other cultures' attitudes, behaviors and beliefs without compromising [their] own" (Malkinson, 2003). Lack of communication skills "only serves to undermine the whole profile and image of the professional engineer" (Reimer, 2002, p. 35). 


\section{Demands for oral and written communication}

The skills required in the engineering profession at the international level are extensive. These include presenting technical oral presentations, conducting telephone conversations on technical or commercial matters, preparing reports of laboratory experiments plus daily language demands such as reading and writing manuals, instructions, commercial letters and e-mails (Gomleksiz, 2007). Numerous reports highlight the significance of oral and written English communication for success in the workplace. In particular, Batley (1998), Myles (2009), Kassim \& Radzuan (2008), Chen (2006) and Freeman (2003) draw attention to oral communication; and Artemeva (1998) and Andrews (2003), written communication.

The importance of oral communication for engineering students and engineers has been widely reported, with emphasis on non-native speakers of English. Reviewing the literature, Batley (1998) concludes that many engineers may have strong quantitative skills while remaining comparatively weak in verbal skills. Engineers are limited in their ability to effectively present themselves. Myles (2009) stresses the challenges that English as a second language (ESL) engineering students may face while on their full time work placements such as participating in meetings, team projects and other professional interactions. Generally, second language learners have proven their capabilities to interact and communicate successfully in their native languages. However, they often struggle in English. Many learners are anxious about making grammatical mistakes (Kassim \& Radzuan, 2008). Chen (2006) studied the communication needs of Chinese technical personnel in mechanics, computer science and electrical engineering. Speaking was considered the most difficult skill and the one that learners most wanted to improve. In another report, Freeman (2003) found that undergraduate engineering students at all levels, both native and non-native English speakers, desired further training in oral presentations and professional conversations. Their desire for training increased as they approached graduation.

While oral communication in English depends on an organization's level of commitment to international collaboration (Kaewpet, 2009), report writing in English is an absolutely vital activity in international communication. At a Canadian high-tech company that collaborated with Russian counterparts, engineers communicated on projects through periodic reports. Even though the language of the reports was English, the engineers had to understand differences in engineering practices as well as the language and culture of each country. They learned about differences in tone, organization, format and perceptions of appropriate content. The knowledge obtained prevented misunderstandings among the collaborators and ensured success of the projects (Artemeva, 1998). The importance of report writing can be observed in many other situations. At an American university, special courses in technical communication were designed taking in to account "[t]he roar of complaints from industrial employers and graduate engineers and scientists themselves about the lack of adequate preparation in writing in the [university] curriculum" (Andrews, 2003). In response, engineering students were required to write reports reviewing the literature on a specific topic, report on selecting materials for specific engineering applications and write about applying fundamentals of engineering to solve practical problems. In another context, a discipline-specific system of writing instruction was designed, refined and evaluated to instructors to help students develop more effective writing skills and strategies. Hanson \& Williams (2008) pointed out that engineering faculty members have realized the importance of communication skills in the workplace and have added these skills to their courses.

\section{A sociolinguistic approach}

A sociolinguistic approach inherently recognizes that understanding of the social practice in which language is situated is a significant factor of effective communication (Munby, 1978; Long, 2005). This school of thought can be summarized by this typical course description: "[t]he major goals of this course are to facilitate the acquisition of rhetorical skills and strategies necessary for students to successfully integrate into their engineering school environment and to facilitate their transition to the workplace" (Artemeva, Logie \& St-Martin, 1999). Sociolinguistic thought explains that "[e]ffective communication begins with rhetorical considerations, resulting in a trade-off of the interests of the target audience, the communicator's organizational and communicative goals (e.g., to inform, persuade or impress), and the context of the communication" (Brinkman \& Geest, 2003). Another important cornerstone of sociolinguistic education is that "[w]riting assignments in English classes should be adapted to real readers in real situations, simulating as closely as possible what students will find on the job" (Andrews, 2003).

For practical application in instruction, a sociolinguistic lens includes a look at a communicative event and profiling its information. This process includes a communication setting, a communication domain (educational, occupational or transitional), subject content, an attitudinal tone (e.g., formal), a communicator, a person with whom the communicator interacts, the variety of English used and the target level required (Munby, 1978; 
Kaewpet, 2009).

The transitional domain aims at training learners in a study situation for the skills required in a work scenario. The variety of English used can be local, ELF (English as a lingua franca) or EIL (English as an international language). The English variety can be classified as local when engineers who share the same first language communicate in English through e-mails because their boss is a native speaker of English.

This framework has been employed successfully for profiling communication needs of Thai civil engineering students (Kaewpet, 2009). This paper takes a step further by analyzing the three most essential communication skills in engineering - oral presentations, professional conversations and report writing.

\subsection{Oral presentations}

Engineering students and engineers often report being week in oral presentations. In the context of the University of Manitoba in Canada (Mann, Ingram, Dick, Petkau \& Britton, 2007), students realized that their communication effort was not simply an academic exercise, but a real-world challenge. Engineering students enrolled in design courses co-taught by English and engineering professors. They were assigned to present a literature review and an open design project obtained from industry, required to receive feedback from classmates, professors and industry representatives, and reciprocally evaluate classmates' oral presentations. The students were expected to apply the skills from the educational context to an occupational situation. Therefore, the communication took place in a transitional domain. The attitudinal tone was noticeably academic and technical. The communicators were from different linguistic backgrounds including English native speakers. Therefore, the variety of English could be classified as ELF and/or EIL. The target language level required for communication was native or near-native in order to accomplish such tasks.

\subsection{Professional conversations}

Engineers rarely work alone. They often discuss tasks and duties among colleagues, subordinates, superiors and external partners (Brinkman \& Geest, 2003). In one of the most common authentic situations identified by ten multi-national chemical engineering engineers, chemical engineering students were trained to negotiate conflicts arising at workplaces (Kassim \& Radzuan, 2008). The students resolved conflicts and solved problems in role-play situations. The unit of study covered topics including roles in a conflict, conflicts within organizations, conflicts with external correspondences, conflicts over business ideas, decisions and actions. The students were trained in a transitional domain and the communication was formal and technical. The communication took place among the students themselves but might have involved those with different first languages. The target level of communication was likely to be near English-native, as the communication required high-order thinking skills.

\subsection{Report writing}

Report writing is one of the competency gaps among new engineers (Society of Manufacturing Engineers Education Foundation, 1997).Artemeva, Logie \& St Martin, (1999) assigned students one major course project that involved writing a formal business letter, proposal, progress report and completion report. The course was designed to enhance students' opportunities for collaborative discussion and feedback in which they gradually become members of the discourse community. The focus of the instruction was to make the communication course part of the students' engineering learning experience. The situation was actually created to help transition to the workplace. One of the subjects chosen by the students was introduction to engineering materials and one content area involved methods of corrosion prevention in metals. The attitudinal tone of the communication was not always formal and technical. For example, newsgroup communications were informal and dialogic. The students interacted with experienced writers including advanced engineering students, teaching assistants and instructors. The course was taught in a North American university. Therefore, the variety of English used in this situation was local, where the communicators were all native speakers of English.

\section{Conclusion}

The engineering profession demands engineering graduates with oral and written English communication competency. The sociolinguistic perspective sheds light on giving more importance to the discourse practice in which English is needed, which should inform English instruction. More emphasis will need to be placed on training in authentic communicative events, particularly those necessary in the workplace. Transition of skills from the classroom to the workplace is expected by employers. Subject content should be discipline-specific to prepare students adequately for effective communication (Boyd \& Hassett, 2000; Andrews, 2003). As seen from the publications, the required comprehensibility of communication is close to the level of native speakers; this should be kept in mind during preparation of lessons. The literature review also indicates that requirements may differ from context to context (Long, 2005) and from discipline to discipline (Artemeva, Logie \& St-Martin, 
1999). It cannot be assumed that engineering or English use in engineering are the same everywhere (Artemeva, 1998: Reimer, 2002). More importantly, the findings of the analysis in the current report were from studies that were not based on sociolinguistic theory. Further examination of the required English oral and written communications in relation to an individual context could lead to satisfactory impact on engineering students and engineers' communication demands.

\section{References}

Accreditation Board for Engineering and Technology, Inc. (1998-2010). Criteria for accrediting engineering programs. [Online]

Available: http://www.abet.org/Linked\%20Documents-UPDATE/Criteria\%20and\%20PP/E001\%2010-11\%20EAC\%20Crit eria\%201-27-10.pdf (January 15, 2011)

Andrews, D. C. (2003). An Interdisciplinary Course in Technical Communication. Technical communication, 50(4).

Available:

http://find.galegroup.com.mate.lib.unimelb.edu.au/itx/infomark.do?\&contentSet=IAC-documents\&type=retrieve $\&$ tabID $=$ T002\&prodId $=$ EAIM

$\&$ docId $=$ A111165961\&source $=$ gale $\&$ srcprod=EAIM\&userGroupName= $=$ unimelb\&version $=1.0>\quad$ (January 25 , 2006)

Artemeva, N. (1998). The Writing Consultant as Cultural Interpreter: Bridging Cultural Perspectives on the Genre of the Periodic Engineering Report. Technical communication quarterly, 7. [Online] Available: http://proquest.umi.com.mate.lib.unimelb.edu.au/pqdlink?did=33468791\&sid=2\&Fmt=4\&clientId=14623\&RQT $=309 \&$ VName $=$ PQD (January 25, 2006)

Artemeva, N., Logie, S., \& St-Martin, J. (1999). From Page to Stage: How Theories of Genre and Situated Learning Help Introduce Engineering Students to Discipline-specific Communication. Technical communication quarterly, $\quad 8 . \quad$ [Online] Available: http://proquest.umi.com.mate.lib.unimelb.edu.au/pqdlink?did=46194788\&sid=2\&Fmt=4\&clientId=14623\&RQT $=309 \&$ VName $=$ PQD $($ January 25, 2006)

Batley, T. (1998). Management Training of Professional Engineers in New Zealand. Journal of European industrial training, 22(7), 309-312. http://dx.doi.org/10.1108/03090599810230713

Björkman, B. (2008). So Where We Are: Spoken Lingua Franca English at a Swedish Technical University. English today, 24(2), 11-17. http://dx.doi.org/10.1017/S0266078408000187

Boyd, G., \& Hassett, M. F. (2000). Developing Critical Thinking Skills in Engineering and Technology Students. Journal of engineering education. October, 409-412. [Online] Available: http://www.jee.org/2000/october/299.pdf (January 15, 2011)

Brinkman, G. W, \& Geest, T.M v d. (2003). Assessment of Communication Competencies in Engineering Design Projects. Technical communication quarterly, 12(1). [Online] Available http://proquest.umi.com.mate.lib.unimelb.edu.au/pqdlink?did=429563611\&sid=1\&Fmt=4\&clientId=14623\&RQ $\mathrm{T}=309 \& \mathrm{VName}=\mathrm{PQD}($ January 25,2006$)$

Chen, Y. (2006). From Common Core to Specific. The Asian ESP journal. June 2006(1), 1-11. [Online] Available: http://www.asian-esp-journal.com/June_2006_yc.php (January 15, 2011)

European Accreditation of Engineering Programmes. (2008). EUR-ACE Framework Standards for the Accreditation of Engineering Programmes. AOnline] Available: http://www.feani.org/webenaee/pdf/EUR-ACE_Framework_Standards_20110209.pdf (January 15, 2011)

Freeman, J. (2003). The Science of Conversation: Training in Dialogue for NNS in Engineering. IEEE transactions on professional communication. 46(3), 157-167. http://dx.doi.org/10.1109/TPC.2003.816791

Gömleksiz, M.N. (2007). Effectiveness of Cooperative Learning (jigsaw II) Method in Teaching English as a Foreign Language to Engineering Students (Case of Firat University, Turkey). European journal of engineering education. 32(5), 613-625. [Online] Available: http://cat.inist.fr/?aModele=afficheN\&cpsidt=19161210 (January $15,2011)$

Graddol, D. (1997, 2000). The Future of English. [Online] Available: http://www.ocol-clo.gc.ca/docs/f/Future_of_English.pdf (January 15, 2011)

Hanson, J. H, \& Williams, J. M. (2008). Using Writing Assignments to Improve Self-assessment and Communication Skills in an Engineering Statistics Course. Journal of engineering education. 97(4), 515-529. 
[Online]

Available:

http://www.docstoc.com/docs/41209552/Using-Writing-Assignments-to-Improve-Self-Assessment-and-Commu nication-Skills-in-an-Engineering-Statics-Course (January 15, 2011)

Hill, P., \& Zyl, S.V. (2000). English and Multilingualism in the South African Engineering Workplace. World Englishes. 21(1), 23-25. http://dx.doi.org/10.1109/10.1111/1467-971X.00229

Jenkins, J. (2000). English as a Lingua Franca: Interpretations and Attitudes. World Englishes, 28(2), 200-207. [Online] Available: http://wwwhomes.uni-bielefeld.de/sgramley/Jenkins_ELF.pdf (January 15, 2011)

Kaewpet, C. (2009). Communication Needs of Thai Civil Engineering Students. English for specific purposes. 28(4), 266-278. http://dx.doi.org/10.1016/j.esp.2009.05.002

Kassim, H., \& Radzuan, N. R. M. (2008). Resolving Conflict: Enhancing Engineering Students' English. The international journal of learning, 14(11), 51-60. [Online] Available: http://ijl.cgpublisher.com/product/pub.30/prod.1564 (January 15, 2011)

Long, M. H. (2005). Methodological issues in learner needs analysis. In M. H. Long. (Ed.). Second language needs analysis (pp. 19-76). Cambridge: Cambridge University Press. http://dx.doi.org/10.1017/CBO9780511667299.002

Malkinson, T. (2003). The Global Engineer: Succeeding without Boundaries. [Online] Available: $\mathrm{http} / / / w w w . t o d a y s e n g i n e e r$. org/2003/Jun/global.asp (January 15, 2011)

Mann, D.D., Ingram, S, Dick, K.J., Petkau D.S., \& Britton, M.G. (2007). An Experiment in Integrating Communication into the Biosystems Engineering Design Trilogy. International journal of English education. 23(4), 645-649. [Online] Available: http://www.ingentaconnect.com/content/intjee/ijee/2007/00000023/00000004/art00005;jsessionid=3s91c6piigts5 .alexandra (January 15, 2011)

Martin, R., Maytham, B., Case, J., \& Fraser, D. (2005). Engineering Graduates' Perceptions of How Well They were Prepared for Work in Industry. European journal of engineering education, 30(2), 167-180. http://dx.doi.org/10.1080/03043790500087571

Munby, J. (1978). Communicative syllabus design: a sociolinguistic model for defining the content of purpose-specific language programmes. Cambridge: Cambridge University Press.

Myles, J. (2009). Oral Competency of ESL Technical Students in Workplace Internships. TESL-EJ, 13(1). [Online] Available: http://www.tesl-ej.org/wordpress/issues/volume13/ej49/ej49a2/ (January 15, 2011)

Reimer, M. J (2002). Investigation into the Development of English and Communication Skills for the Modern Engineer within a Cultural Context: A Research Scheme. World Transactions on engineering and technology education, 1(1), 23-28.

Society of Manufacturing Engineers Education Foundation. (1997). Manufacturing Education Plan: Phase 1 Report-Industry Identifies Competency Gaps among Newly Hired Engineering Graduates. [Online] Available: http://www.sme.org/cgi-bin/getsmepg.pl?/new-sme.html\&\&\&SME\& (January 15, 2011) 